\title{
Nanoplankton assemblages in maritime Antarctic lakes: characterisation and molecular fingerprinting comparison
}

\author{
Fernando Unrein ${ }^{1, *}$, Irina Izaguirre ${ }^{2}$, Ramon Massana ${ }^{1}$, Vanessa Balagué ${ }^{1}$, \\ Josep M. Gasol ${ }^{1}$ \\ ${ }^{1}$ Departament de Biologia Marina i Oceanografia, Institut de Ciències del Mar-CMIMA, CSIC, \\ Passeig Marítim de la Barceloneta 37-49, 08003 Barcelona, Catalonia, Spain \\ ${ }^{2}$ Departamento de Ecología, Genética y Evolución, Facultad de Ciencias Exactas y Naturales, Universidad de Buenos Aires, \\ Pabellón II, Ciudad Universitaria, C1428EHA Buenos Aires, Argentina
}

\begin{abstract}
The composition of planktonic eukaryotes in the size fraction 3-20 $\mu \mathrm{m}$ of 10 maritime Antarctic lakes was studied by denaturing gradient gel electrophoresis (DGGE). Microscopic observations were also carried out to compare the results obtained by this molecular fingerprinting technique with morphological data. Six lakes from Hope Bay (Antarctic Peninsula) and 4 from the Potter Peninsula (King George Island) were sampled during the austral summer of 2003. These lakes were of different trophic status and covered a wide range of limnological features. Previous studies of the planktonic communities of these lakes revealed high nanoflagellate abundance and biomass, but their taxonomic identification was usually uncertain due to their similarity in size and shape. Here, the application of DGGE allowed both a comparison of the structure of the nanoplanktonic communities and an identification of the dominant populations through sequencing of the most prominent DGGE bands. The most important organisms in these lakes were the Chrysophyceae, represented in the DGGE gel by 5 different band positions and identified by microscopy in 5 different morphotypes, including uniflagellated and biflagellated naked organisms: 1 sequence belonged to the Chrysosphaerales, 2 closely related bands (likely 2 species from the same genus) belonged probably to the Ochromonadales (unicellular biflagellates), while the other 2 bands could not be assigned to any defined chrysophyte group. Sequences related to Chlorophyceae, Bacillariophyceae and probably Cercozoa were also retrieved. A Dictyochophyceae belonging to the order Pedinellales is reported for the first time in freshwater Antarctic ecosystems. Microscopic observations suggest that this phytoplanktonic organism most likely corresponds to Pseudopedinella. Most of the lakes shared several common sequences, such as 2 chrysophyte bands, which suggests the existence of well-adapted nanoplanktonic species dispersed throughout the Antarctic lakes. However, some sequences appeared exclusively in specific lakes, which seems to be related to the trophic status of the water bodies and probably also to the local conditions of the maritime Antarctic regions sampled.
\end{abstract}

KEY WORDS: Freshwater nanoplankton · Antarctic lakes · DGGE $\cdot 18 \mathrm{~S}$ rDNA

\section{INTRODUCTION}

Antarctic lakes are characterised by relatively simple food webs and low species diversity, with copepods as the top predators (Tranvik \& Hansson 1997). The microbial food web, therefore, dominates these envi- ronments (Laybourn-Parry 1997). Among the microbial components, phototrophic nanoplankton may represent up to $90 \%$ of the total planktonic algal biomass in certain lakes (Allende \& Izaguirre 2003). Furthermore, nanoplanktonic algae are usually the most important primary producers in these lakes. For example, in 
Signy Island, this fraction contributes between 49 and $69 \%$ of carbon fixation (Ellis-Evans 1991). In addition, bacterivory by heterotrophic nanoflagellates may remove between 0.1 and $32 \%$ of the bacterial production per day (Laybourn-Parry et al. 1995, Bell \& LaybournParry 2003), while mixotrophic nanoplanktonic algae are able to remove up to $16 \%$ of the bacterial biomass, equivalent to $>100 \%$ of in situ bacterial production (Bell \& Laybourn-Parry 2003).

Flagellated algae dominate the nanoplanktonic fraction of the phytoplankton community in Hope Bay lakes (Antarctic Peninsula) (Izaguirre et al. 1993, 1998, 2003, Allende \& Izaguirre 2003). In particular, Chrysophyceae dominate algal biomass in most oligotrophic lakes of the region, in which Ochromonas and Chromulina are often reported as the dominant genera, whereas volvocaleans (Chlorophyceae) dominate in eutrophic systems. Different flagellated algae, including Chrysophyceae, Chlorophyceae, Prasinophyceae and Cryptophyceae, have also been reported to be very abundant in many other Antarctic lakes (Laybourn-Parry et al. 1997, Butler 1999a, Mataloni et al. 2000, McKnight et al. 2000, Izaguirre et al. 2001, Marshall \& Laybourn-Parry 2002, Bell \& Laybourn-Parry 2003). The motility, pigment adaptation to low light intensity, and mixotrophic behaviour of some flagellates are adaptive advantages that allow them to dominate the plankton community in Antarctic ecosystems, subject to periodic freezing (Priddle et al. 1986, Burch 1988, Laybourn-Parry et al. 2000, McKnight et al. 2000, Izaguirre et al. 2003).

Despite the essential role of nanoplanktonic organisms in Antarctic freshwater environments, the diversity and genetic affinities of most of the dominant taxa remain uncertain. Most phytoplankton surveys in Antarctic lakes lack a detailed floristic list. In many cases, taxa are identified at the generic level or, most commonly, appear as unidentified algae (LaybournParry et al. 1996, 1997, Butler 1999b, Roberts et al. 2000, Vinocur \& Unrein 2000, Izaguirre et al. 2001). Recent surveys conducted in the lakes of Hope Bay identified several different nanoplanktonic entities (Allende \& Izaguirre 2003, Izaguirre et al. 2003), but their precise taxonomic affiliation was difficult to achieve through conventional microscopic techniques.

Reviewing the diversity of Antarctic microbiota, Vincent (2000) stressed the importance of using new analytical approaches, particularly molecular techniques, in order to advance in the understanding of the phylogeny, biodiversity and evolution of Antarctic microbes. There is also an additional interest: although Antarctica is not impermeable to the invasion of microbiota coming from other continental water bodies, the isolation of this continent favours genetic divergence by environmental selection of adaptive strategies (Vincent
2000). Molecular studies on prokaryotes have shown that considerable differences exist between the Antarctic species and closely related taxa from other latitudes (Franzmann 1996). Vincent et al. (2000) also found important differences between Arctic and Antarctic strains of picocyanobacteria.

Molecular methods have been successfully applied to analyse both prokaryote and eukaryote assemblages in marine and freshwater ecosystems (e.g. Giovannoni et al. 1990, Fuhrman et al. 1992, Díez et al. 2001a, Moon-van der Staay et al. 2001). These studies have allowed the detection of different microorganisms that were previously impossible to discriminate due to their small size and lack of distinctive morphologic features. Thus, new groups of marine bacteria and archaea were identified using 16S rRNA genes (Giovannoni et al. 1990, DeLong 1992, Fuhrman et al. 1992). Similarly, the surveys carried out by Díez et al. (2001a), López-García et al. (2001) and Moon-van der Staay et al. (2001) revealed an unexpected diversity of marine small eukaryotes in the size fraction between 0.2 and $5 \mu \mathrm{m}$. Some of the novel lineages identified account for a significant fraction of marine microbial functional groups that until recently have remained phylogenetically uncharacterised (Massana et al. 2002).

Denaturing gradient gel electrophoresis (DGGE) allows DNA fragments of similar size but of different base sequence to be separated (Muyzer et al. 1997), and is also a useful tool for the comparison of microbial assemblages and identification of numerically dominant community members (Torsvik et al. 1998). Díez et al. (2001b) applied DGGE to study the diversity of picoeukaryotes in marine assemblages. DGGE has also been used in freshwater systems, to study the changes in bacterioplankton composition (Lindström 2000, 2001, Casamayor et al. 2002, Lindström \& Leskinen 2002) and eukaryote community composition (van Hannen et al. 1998, 1999). In Antarctic lakes, Pearce (2000) and Pearce \& Butler (2002) used DGGE to assess the diversity of bacterioplankton in these environments. More recently, these authors surveyed the bacterioplankton composition of a Signy Island maritime oligotrophic lake, combining different molecular techniques to compare bacterial assemblage composition with that of temperate water bodies (Pearce 2003, Pearce et al. 2003). However, the eukaryotic plankton in freshwater Antarctic ecosystems has never been studied using molecular techniques.

In the present study, we compare the planktonic nanoeukaryotic assemblages of maritime Antarctic lakes by applying a molecular fingerprinting approach in parallel with microscopic observations. We studied lakes from 2 distant Antarctic areas and included as many diverse lake types as possible. The DNA extracted from cells between 3 and $20 \mu \mathrm{m}$ in size was 
used in a PCR amplification of 18S rRNA genes, which were subsequently separated by DGGE. The phylogenetic composition was analysed by sequencing excised DGGE bands. This information was compared with microscopic information on the dominant organisms observed in the samples. We discuss the similarities and differences in the nanoeukaryotes that dominated the surveyed lakes.

\section{MATERIALS AND METHODS}

Study sites. The lakes are located in 2 different regions of the maritime Antarctica: Hope Bay (Antarctic Peninsula) and the Potter Peninsula (King George Island). Both regions include Antarctic Specially Protected Areas (ASPA 148 and 132, respectively). Hope Bay is situated at the northern end of the Antarctic Peninsula ( $\left.63^{\circ} 24^{\prime} \mathrm{S}, 57^{\circ} 00^{\prime} \mathrm{W}\right)$. The southwestern margin of the bay is characterised by many shallow water bodies, mostly of glacial origin. Since Hope Bay hosts one of the largest Pygoscelis adeliae penguin rookeries, the lakes located in its vicinity are subjected to natural eutrophication. Six water bodies from Hope Bay were sampled in this study: Boeckella, Esperanza, Flora, Encantado, Chico and Pingüi. Boeckella Lake is the biggest of the region, about $600 \mathrm{~m}$ away from the Argentinean Esperanza station, and is influenced by the inputs of the nearby penguin rookery. Esperanza, Flora and Encantado Lakes are located in Five Lakes Valley, about $3 \mathrm{~km}$ away from the station; they are connected by a small stream, and all of them are oligotrophic. Chico Lake is also oligotrophic and is situated on the Mount Flora shelf, at $100 \mathrm{~m}$ above sea level. Pingüi Pond is a very shallow eutrophic water body within the penguin rookery. The geological and climatic characteristics of Hope Bay, as well as the morphometric features of the lakes, have been previously described (Izaguirre et al. 1998, 2003).

Potter Peninsula $\left(62^{\circ} 14^{\prime} \mathrm{S}, 58^{\circ} 38^{\prime} \mathrm{W}\right)$ is located at the southwestern extreme of King George Island, the largest of the South Shetland Islands. This region includes a great number of ponds and lakes. A complete description of the area and the main characteristics of the water bodies are reported in Vinocur \& Unrein (2000). For the present study, 4 lakes of Potter Peninsula were selected: Lakes L, M, W and Z, according to the denomination given in the map of Vinocur \& Unrein (2000). Lake L is located next to the glacier, Lake $\mathrm{M}$ in a hilly area about $1000 \mathrm{~m}$ away from the Argentinean Station Jubany, and Lakes W and Z are ca. 100 to $200 \mathrm{~m}$ away from the station. All water bodies are oligotrophic. The main geographic, morphometric and limnological information of all 10 lakes studied is summarised in Table 1.

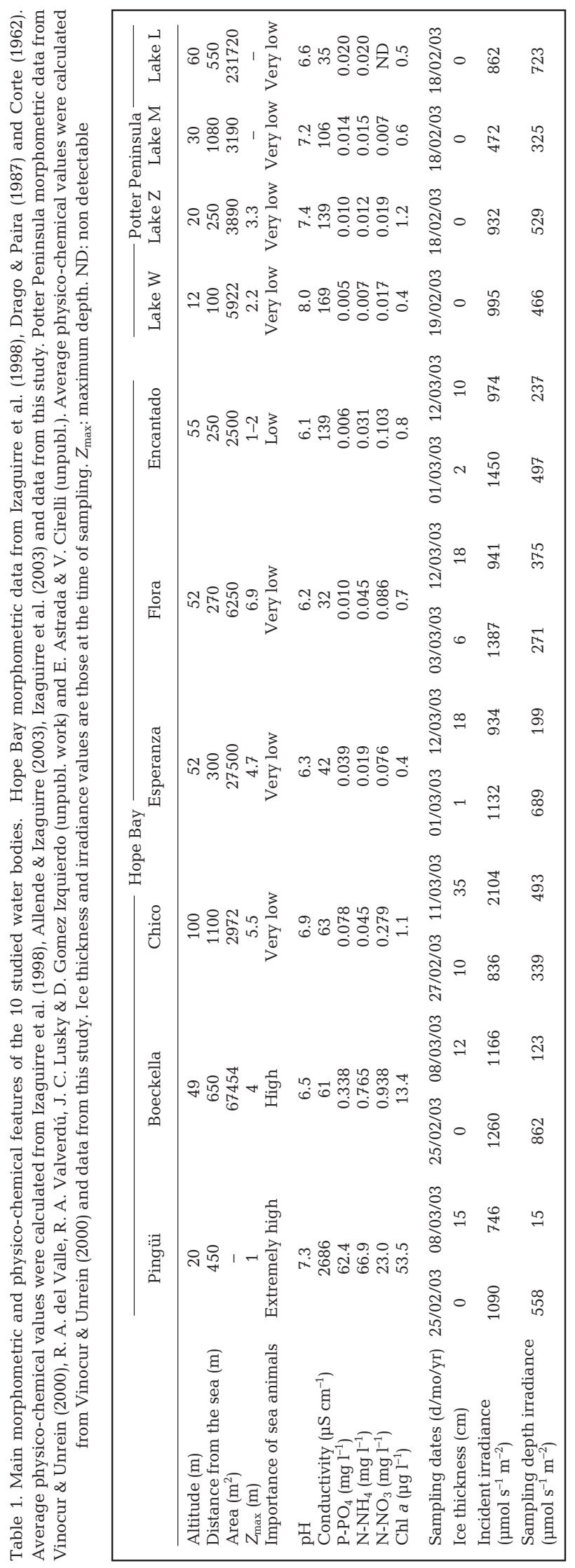


Sampling and physical-chemical measurements. Samples were collected during the 2003 Antarctic summer (18 February to 12 March). The lakes from Hope Bay were sampled on 2 different dates, while the water bodies from Potter Peninsula were sampled only once. Samples were collected with a plastic bottle from a single site near the shore of the lake, beneath the surface during the ice-free periods or immediately below the ice layer when the lakes were frozen. Temperature, $\mathrm{pH}$ and conductivity were measured in situ with a Hanna HI8314 and HI8033 portable meter (Hanna Instruments). Incident and underwater irradiance were measured with a Li-Cor PAR spherical quantum sensor (Li-250). Phosphate, nitrate and ammonia concentrations were determined at each research station laboratory, using a Hach DR/2010 spectrophotometer and their corresponding kits of reagents (the detection limit for all nutrients being $0.001 \mathrm{mg} \mathrm{l}^{-1}$ ). Samples for chlorophyll a (chl a) and nutrient analyses were immediately filtered through Whatman GF/F. Concentrations of chl $a$, corrected for phaeopigments, were determined by spectrophotometry before and after acidification $(\mathrm{HCl} 0.1 \mathrm{~N})$, using hot ethanol $\left(60\right.$ to $\left.70^{\circ} \mathrm{C}\right)$ as solvent (Nusch 1980). The equations published by Marker et al. (1980) were used for the calculations.

Taxonomic analyses of the nanoplankton communities were based on microscopic observations of living and lugol-fixed specimens at the research station laboratory. Samples for quantitative analyses of nanoplankton were preserved with acidified 1\% Lugol's iodine solution. Counts were performed using an inverted microscope according to Utermöhl (1958). Replicate chambers were left to sediment for at least $24 \mathrm{~h}$, and counting errors were estimated following recommendations given by Venrick (1978).

Community DNA extraction. For DNA extraction, freshwater from the different lakes was collected with a plastic carboy, pre-filtered in situ by pouring the water through a $50 \mu \mathrm{m}$ net and collected in a plastic bottle. Depending on the trophic status of the lake, between 1 and $2.5 \mathrm{l}$ of sample were filtered with a vacuum pump first through a $20 \mu \mathrm{m}$ pore-size polycarbonate filter and then through a $3 \mu \mathrm{m}$ pore-size polycarbonate filter (diameter $47 \mathrm{~mm}$; Poretics). Each $3 \mu \mathrm{m}$ filter was placed in a criovial with $1.5 \mathrm{ml}$ of lysis buffer (40 mM EDTA, $50 \mathrm{mM}$ Tris- $\mathrm{HCl}, 0.75 \mathrm{M}$ Sucrose), stored for $40 \mathrm{~d}$ in liquid nitrogen and then stored at $-80^{\circ} \mathrm{C}$ until nucleic acid extraction was performed in the laboratory.

Nucleic acid extraction began with the addition of lysozyme (final conc.: $1 \mathrm{mg} \mathrm{ml}^{-1}$ ) and incubating the filters at $37^{\circ} \mathrm{C}$ for $45 \mathrm{~min}$. Subsequently, SDS (sodium dodecyl sulfate; final conc.: $1 \%$ ) and Proteinase $\mathrm{K}$ (final conc.: $0.2 \mathrm{mg} \mathrm{ml}^{-1}$ ) were added, and the filters were incubated at $55^{\circ} \mathrm{C}$ for $60 \mathrm{~min}$. The lysates were purified twice by extraction with an equal volume of phenol-chloroform-isoamyl alcohol (25:24:1), and the residual phenol was removed by extraction with an equal volume of chloroform-isoamyl alcohol (24:1). Nucleic acid extracts were further purified, desalted, and concentrated with Milli-Q sterile water in a Centricon-100 concentrator (Millipore) to a volume of 100 to $200 \mu \mathrm{l}$. The integrity of the total DNA was checked by agarose gel electrophoresis. Nucleic acid extracts were stored at $-80^{\circ} \mathrm{C}$ until analysis.

PCR amplification of 18S rRNA gene fragments. One $\mu l$ of extracted DNA was used as a template for PCR amplification of eukaryotic 18S rDNA. A set of primers specific for eukaryotes was used (Díez et al. 2001a): Euk1F (5'-AACCTGGTTGATCCTGCCAGT$\left.3^{\prime}\right)$ and Euk516r-GC (5'-ACCAGACTTGCCCTCC-3') with a $40 \mathrm{bp}$ GC-clamp, which amplifies a fragment approximately $560 \mathrm{bp}$ long. The PCR mixtures $(50 \mu \mathrm{l})$ each contained deoxynucleoside triphosphate at a concentration of $200 \mu \mathrm{M}, 1.5 \mathrm{mM} \mathrm{MgCl}_{2}$, each primer at a concentration of $0.5 \mu \mathrm{M}, 0.15 \mu \mathrm{g} \mathrm{ml}^{-1}$ of BSA, $2.5 \mathrm{U}$ Taq DNA polymerase (Promega), and the PCR buffer supplied with the enzyme. The PCR program included an initial denaturation at $94^{\circ} \mathrm{C}$ for $130 \mathrm{~s}$, followed by 35 cycles of denaturation at $94^{\circ} \mathrm{C}$ for $30 \mathrm{~s}$, annealing at $56^{\circ} \mathrm{C}$ for $45 \mathrm{~s}$, an extension at $72^{\circ} \mathrm{C}$ for $130 \mathrm{~s}$, and a final extension cycle at $72^{\circ} \mathrm{C}$ for $10 \mathrm{~min}$. An aliquot of the PCR product was separated by electrophoresis in a $1 \%$ agarose gel, stained with ethidium bromide $(0.5 \mu \mathrm{g}$ $\mathrm{ml}^{-1}$ ), and quantified by comparison to a standard (Low DNA Mass Ladder; Invitrogen).

Denaturing gradient gel electrophoresis. DGGE was performed with a DGGE-2000 system (CBS Scientific Company) as described previously (Muyzer et al. 1997, Schauer et al. 2000). Electrophoresis was performed with $0.75 \mathrm{~mm}$ thick $6 \%$ polyacrylamide gels (ratio of acrylamide to bisacrylamide, 37.5:1) submerged in $1 \times$ TAE buffer $(40 \mathrm{mM}$ Tris, $40 \mathrm{mM}$ acetic acid, 1 mM EDTA; $\mathrm{pH} 7.4$ ) at $60^{\circ} \mathrm{C}$. Approximately 600 to $800 \mathrm{ng}$ of PCR product from environmental samples were applied to individual lanes in the gel. The gel was run at $100 \mathrm{~V}$ for $16 \mathrm{~h}$ in a linear 45 to $65 \%$ denaturant agent gradient $(100 \%$ denaturant agent was defined as $7 \mathrm{M}$ urea and $40 \%$ deionised formamide). The gels were stained for 45 min in 1× TAE buffer with SybrGold nucleic acid stain (Molecular Probes) and visualised with UV radiation using a Fluor-S MultiImager and the MultiAnalyst imaging software (Bio-Rad).

Digitised DGGE images were analysed using the Diversity Database software (Bio-Rad) as previously described (Schauer et al. 2000). A matrix was constructed, taking into account the presence or absence of individual bands in all lanes and the relative intensity of each band compared to the total band intensity in the lane. A distance matrix was calculated using Euclidean distances and then a cluster was constructed 
applying the UPGMA (unweighted pair-group average) algorithm with Statistica software. Bands 2a and $2 \mathrm{~b}$ were not included in the analyses since their sequences corresponded to a copepod, clearly outside the size fraction targeted.

Sequencing of DGGE bands and phylogenetic analyses. DGGE bands were excised from the gel, resuspended in $20 \mu \mathrm{l}$ of Milli-Q water, and stored at $4^{\circ} \mathrm{C}$ overnight. Thin bands with a weak intensity are difficult to excise and reamplify; therefore, only the more intense bands were chosen. Five $\mu l$ of supernatant was used for PCR reamplification with the original primer set and the PCR product was purified with the Qiaquick PCR Purification kit (QIAGEN). A part of the PCR product was checked by DGGE together with the original sample to verify the correct position of the band, and in the few cases that it yielded more than 1 band it was processed again as described above. Between 30 and $50 \mathrm{ng}$ of the reamplified PCR product was used for a sequencing reaction with the corresponding forward primer (following the program recommended by the manufacturer) with a Bigdye Terminator Cycle Sequencing kit v.3.0 (PE Biosystems) and an ABI PRISM model 377 (v. 3.3) automated sequencer. The sequences obtained (around 500 bases) were compared with public DNA databases using BLAST (Altschul et al. 1997). The CHECK_CHIMERA com- mand of the Ribosomal Database Project (Maidak et al. 2001) was used to rule out possible chimerical structures in our sequences. Our chrysophyte sequences (5 bands) were aligned using ClustalW 1.82 (Thompson et al. 1994) with a selection of $18 \mathrm{~S}$ rDNA chrysophyte sequences based in the tree of Andersen et al. (1999) and including the best BLAST matches in each case. An alignment of 517 positions present in all sequences was used for phylogenetic analyses. Maximum likelihood analysis was carried out using PAUP 4.0b10 (43), with the general time-reversible model assuming a discrete gamma distribution with 6 rate categories and a proportion of invariable sites. Parameters were estimated from an initial neighbour-joining tree.

\section{RESULTS}

The 10 studied water bodies ranged from oligotrophic to eutrophic (Table 1). Most lakes were oligotrophic, including all 4 lakes from Potter Peninsula, while the lakes more influenced by the penguin rookeries in Hope Bay were mesotrophic (Boeckella) or eutrophic (Pingüi).

The 16 samples (fraction 3 to $20 \mu \mathrm{m}$ ) collected in all lakes (6 lakes from Hope Bay sampled twice and 4 lakes from Potter Peninsula sampled once) were run in

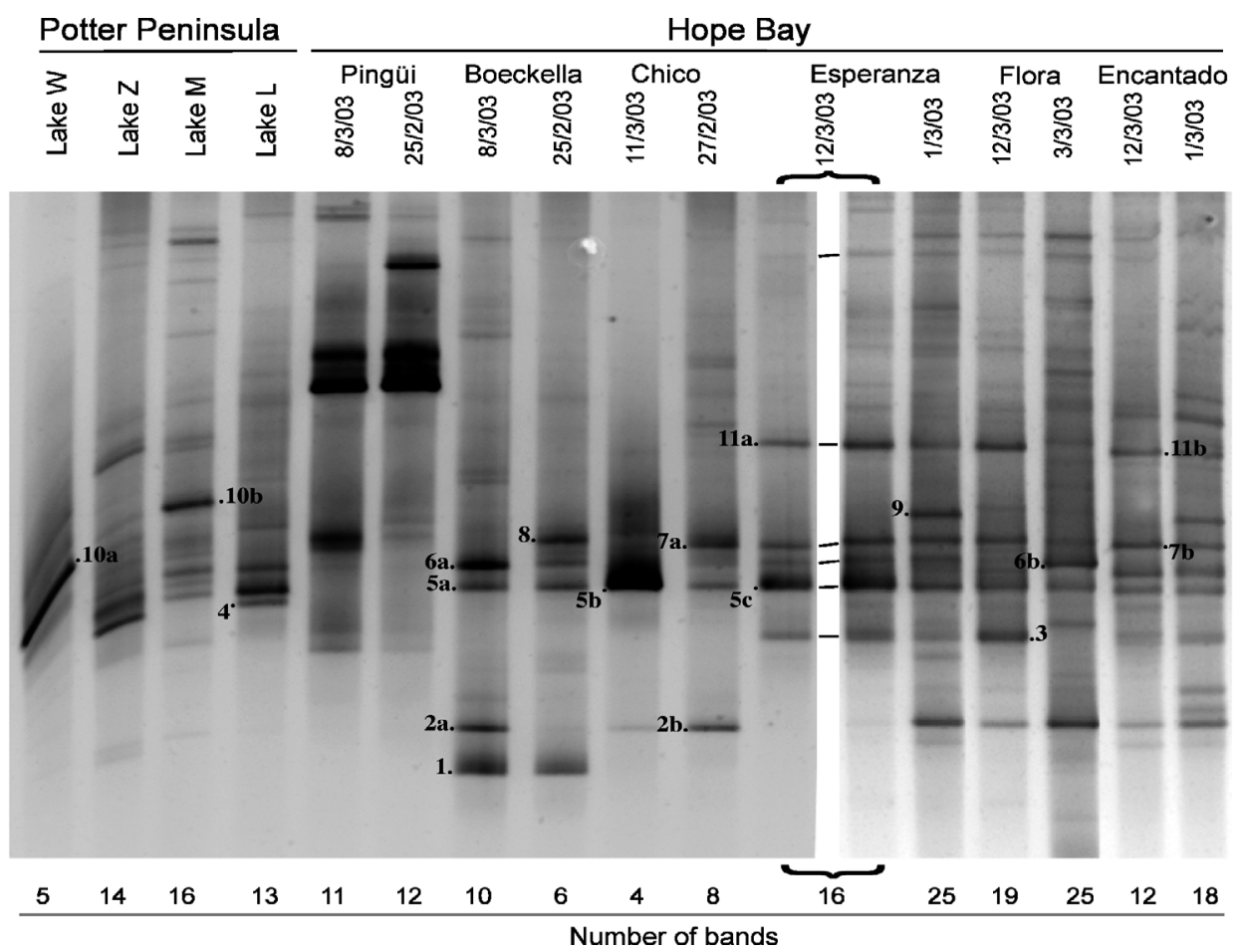

Fig. 1. DGGE gels of the nanoeukaryotic assemblages in the samples from the 10 lakes studied. The portions of images of 2 analysed gels were cut and printed side by side and the corresponding band positions were connected by thin lines. Esperanza lake 12/3/03 (d/mo/yr) appears in both gels to allow for comparison between them. Numbers in gels indicate excised and sequenced bands 
2 DGGE gels (Fig. 1). Three samples were run in both gels to allow for comparison among the gels (only Esperanza 12/3/03 is shown in Fig. 1); thus, positions of the bands in different gels could be unambiguously identified and connected with thin lines. Analysis of the gel gave a total of 214 bands in 47 different positions. The number of bands per sample ranged from 4 to 25 (see bottom of Fig. 1). Pingüi Pond showed the most different fingerprint in comparison to the other lakes, since many of the bands were unique. Band 1 was restricted to Boeckella Lake, while Bands 4 and 10 appeared exclusively in lakes from Potter Peninsula. In contrast, Bands 3 and 11 were present exclusively in oligotrophic lakes, whereas Bands 5 and 6 appeared in almost all the water bodies.

From the position of bands and their relative intensity, we constructed a dendrogram to show the similarities of DGGE fingerprints (Fig. 2). In general, the dendrogram reflects the differences in trophic status among the lakes. Most oligotrophic lakes grouped together. In particular, the 3 connected lakes from Hope Bay (Esperanza, Flora and Encantado Lakes) are highly similar. In contrast, samples from the mesotrophic Boeckella Lake and from the eutrophic Pingüi Pond clustered separately. Chico Lake did not show a clear pattern, while Lakes M and W from Potter Peninsula clustered together probably because they share 1 intense band (Band 10). Samples collected from the same lake at different dates showed some differences but were in general very related.

We excised and sequenced 18 bands from the gel (see Fig. 1). Some bands with the same position were sequenced in different samples in order to confirm that bands with similar melting point (and position) corresponded to the same sequence: Bands 2, 5, 6, 7, 10

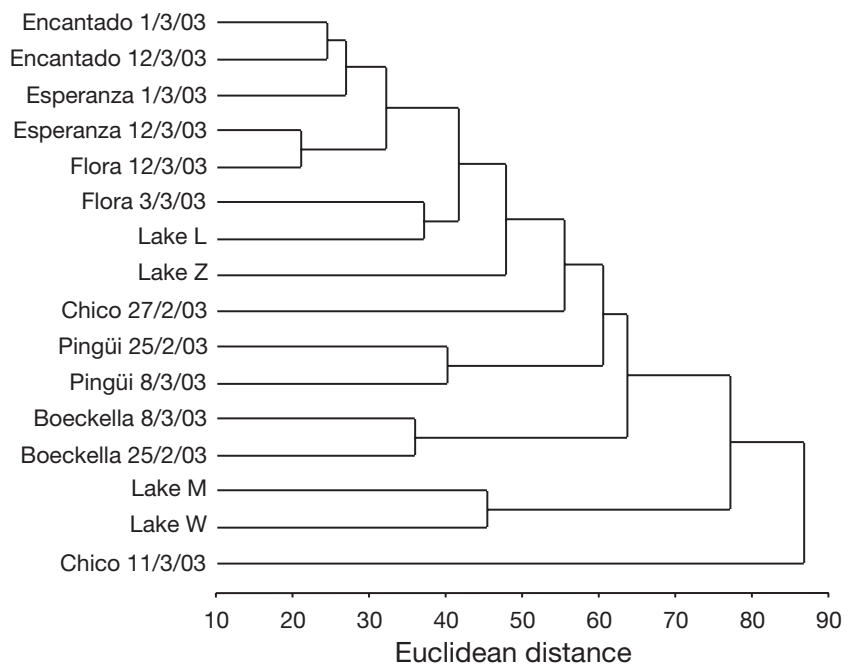

Fig. 2. Clustering of samples calculated on the basis of the intensity matrix: presence and relative intensity of the bands in all samples

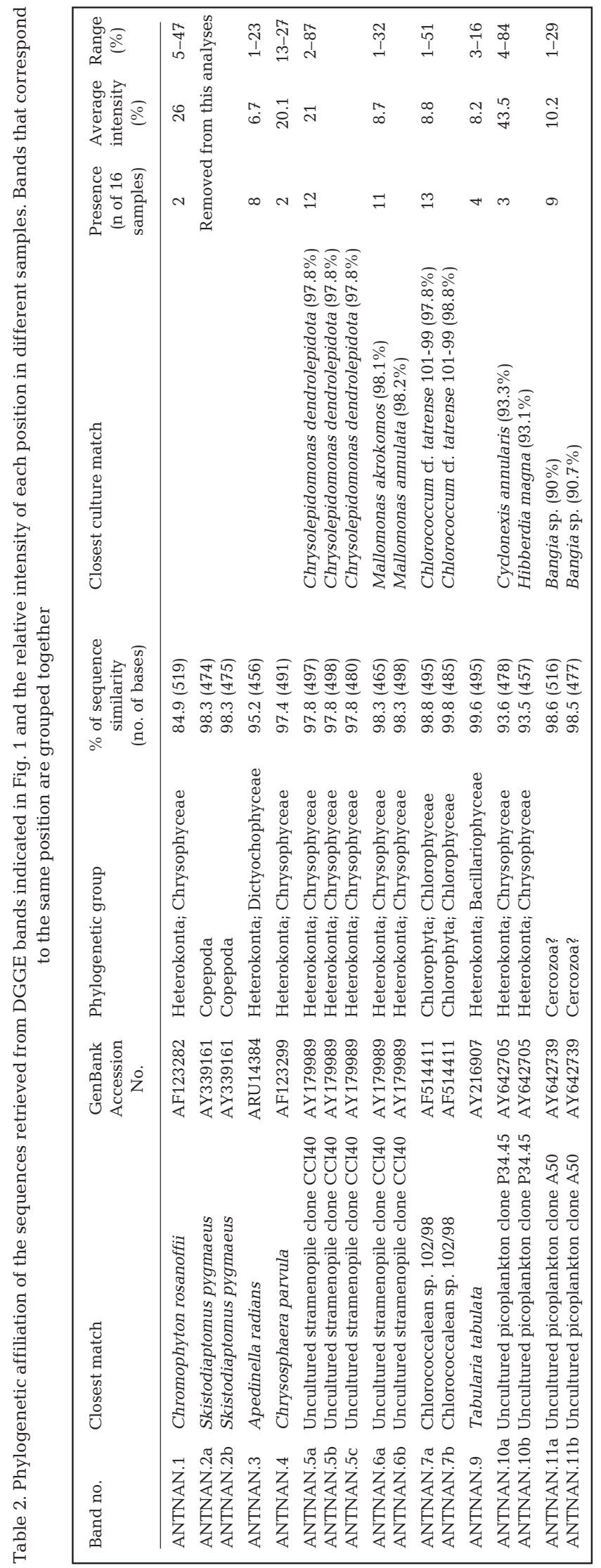


and 11 (Table 2). Sequence similarities among these groups were 100, 99.6 (on average), 99.8, 99.2, 99.8 and $99.2 \%$, respectively, indicating that they indeed corresponded to virtually the same sequence. Therefore, 11 positions from a total of 47 were successfully sequenced. One of these positions (Band 2) corresponded to a copepod, and was excluded from further analyses. Apart from Pingüi Pond samples, the 10 positions belonging to protist organisms accounted for 31 to $96 \%$ of the total band intensity in each lane $(63 \%$ on average), and therefore accounted for most of the DGGE signal. Unfortunately, we could not sequence the 3 intense bands exclusively found for Pingüi Pond. Bands 5, 6 and 7 accounted for a great percentage of intensity in most lakes (Table 2), while Bands 1, 3, 4 and 10, when present, represented a significant share of the total DGGE band intensity of the sample.

The closest matches of the sequences retrieved were determined by BLAST search (Table 2). The number of bases used to calculate similarity values is shown in the table as an indication of the available phylogenetic information. Most of the bands belonged to heterokonts (stramenopiles), and in particular 5 different bands within Chrysophyceae could be distinguished. These 5 sequences were added to a tree of $18 \mathrm{~S}$ rDNA sequences to visualise the relationships among them and with other sequenced chrysophytes (Fig. 3). Band 4 appears within clade $\mathrm{E}$ (according to the reconstruction by Andersen et al. 1999), Bands 5 and 6 seem to be related with clade $\mathrm{C}$, while Bands 1 and 10 could not be assigned to any clade. It is important to stress that even though Bands 5 and 6 are very similar (99.1\%), their sequences differ enough to run separately in the DGGE.

Two more heterokonts were sequenced (Table 2): one band belonged to a Dictyochophyceae with a 95.2\% similarity to Apedinella radians, and the other to a diatom that corresponds to Tabularia tabulata (99.6\%). Band 11 probably belonged to a Cercozoa. Among Chlorophyta, Band 7 had a high similarity with a chlorococcalean strain (99.3\% on average), while Band 8 showed $93.1 \%$ similarity to Raphidonema brevirostra. This last sequence was not included in Table 2 due to its poor quality and shortness (only $248 \mathrm{pb}$ ). Finally, Band 2 belonged to a copepod, undoubtedly Boeckella poppei, the only crustacean found in this pelagic habitat in Hope Bay (Izaguirre et al. 2003). The occurrence of such a zooplankter in the 3-20 $\mu \mathrm{m}$ fraction was the result of either an inefficient prefiltration or the presence of cell body fragments. Therefore, this sequence was excluded from further analysis.

A total of 46 taxa were identified under optical microscopy (Table 3). Many diatom species were recognised, although all the taxa belonged to epilithic organisms. For this reason, their densities were usually low in the plankton (in general $<10$ ind. $\mathrm{ml}^{-1}$ ) with the

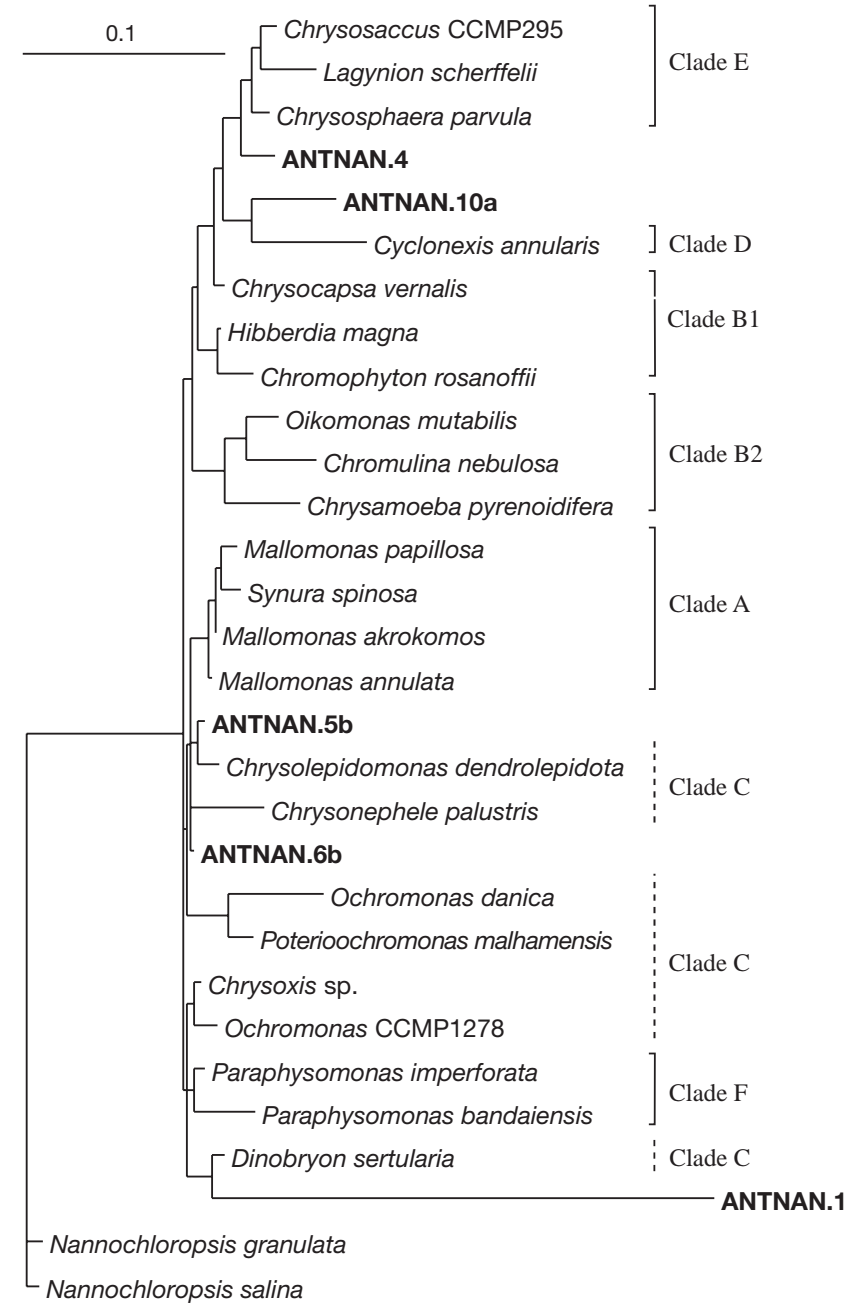

Fig. 3. Phylogenetic tree constructed by maximum-likelihood with the 5 chrysophyte sequences (ANTNAN) retrieved from the DGGE bands (indicated in Fig. 1) and other chrysophyte sequences from GenBank. Two Eustigmatophyceae sequences were also included to root the tree. Positions 5, 6 and 10, which were sequenced in more than 1 sample, were shown only by 1 sequence. The scale bar indicates 0.1 substitutions per position. Clades identified by Andersen et al. (1999) are also indicated

exception of cf. Tabularia tabulata, which varied between 100 and 200 ind. $\mathrm{ml}^{-1}$ in Esperanza and Encantado Lakes, and Pinnularia microstauron, whose density exceeded 700 ind. $\mathrm{ml}^{-1}$ in Boeckella Lake. Considering the strictly planktonic organisms, Chrysophyceae clearly dominated in terms of density in most of the lakes of Hope Bay (Table 4). One of the unidentified Chrysophyceae (unid. 2), which was very small (3 to $4 \mu \mathrm{m}$ ) with only 1 flagella visible under the light microscope, was observed in all the lakes of this region, at densities ranging from 100 to 6200 ind. $\mathrm{ml}^{-1}$. At least 5 different taxa of Chrysophyceae, including 1 Ochromonas-like species (typically with 2 visible flagella), were recognised in the plankton samples, but 
Table 3. Presence of nanoplanktonic taxa observed under light microscopy at each lake during summer 2003. unid.: unidentified

\begin{tabular}{|c|c|c|c|c|c|c|c|c|c|c|}
\hline \multirow[t]{2}{*}{ Taxon } & \multirow{2}{*}{ Pingüi } & \multirow[b]{2}{*}{ Boeckella } & \multicolumn{2}{|c|}{ Hope Bay } & \multirow[b]{2}{*}{ Flora } & \multirow{2}{*}{$\overline{\text { Encantado }}$} & \multirow{2}{*}{$\overline{\text { Lake W }}$} & \multicolumn{2}{|c|}{ Potter Peninsula - } & \multirow{2}{*}{$\overline{\text { Lake I }}$} \\
\hline & & & Chico & Esperanza & & & & Lake Z & Lake M & \\
\hline \multicolumn{11}{|l|}{ Bacillariophyceae } \\
\hline Achnanthes cf. biasolettiana & & & & & & & & $x$ & & \\
\hline Achnanthes delicatula & & & & & & & & $\mathrm{x}$ & $\mathrm{x}$ & $\mathrm{x}$ \\
\hline Achnanthes germanii & & & & $\mathrm{x}$ & & & $\mathrm{x}$ & $\mathrm{x}$ & $\mathrm{x}$ & $\mathrm{x}$ \\
\hline Achnanthes lanceolata var. haynaldii & & & & & & & $\mathrm{x}$ & $\mathrm{x}$ & $\mathrm{x}$ & $\mathrm{x}$ \\
\hline Achnanthes lapponica var. ninckei & & $\mathrm{x}$ & $\mathrm{x}$ & $\mathrm{x}$ & $\mathrm{x}$ & & & & & \\
\hline Achnanthes subatomoides & & $\mathrm{x}$ & & & $\mathrm{x}$ & & & & & \\
\hline Achnanthes spp. & & & & $\mathrm{x}$ & & & & $\mathrm{x}$ & & \\
\hline Amphora cf. duseni & & & & & & & $\mathrm{x}$ & & $\mathrm{x}$ & \\
\hline Cyclotella meneghiniana & & & & & & & & & & $\mathrm{x}$ \\
\hline Fragilaria ulna & & & & & & & & & $\mathrm{x}$ & $\mathrm{x}$ \\
\hline Fragilaria sp. & & & & & $x$ & & & & & \\
\hline Gomphonema clavatum & & & & & & & $\mathrm{x}$ & & $\mathrm{x}$ & \\
\hline Hantzschia amphioxys & & & & & & & & & & $\mathrm{x}$ \\
\hline Luticula muticopsis & $x$ & & & & & & & & & $\mathrm{x}$ \\
\hline Navicula contenta & & & & & & & & & & $\mathrm{x}$ \\
\hline Navicula tabellariaeformis & & & $\mathrm{x}$ & $\mathrm{x}$ & $\mathrm{x}$ & & & & & $\mathrm{x}$ \\
\hline Navicula spp. & & & & & $\mathrm{x}$ & & & $\mathrm{x}$ & $\mathrm{x}$ & $\mathrm{x}$ \\
\hline Nitzschia inconspicua & & & & & & & $\mathrm{x}$ & $\mathrm{x}$ & & $\mathrm{x}$ \\
\hline Nitzschia palea & & & & & & & $\mathrm{x}$ & $\mathrm{x}$ & $\mathrm{x}$ & $\mathrm{x}$ \\
\hline Nitzschia paleacea & & $\mathrm{x}$ & & & $\mathrm{x}$ & & & & & \\
\hline Nitzschia spp. & & & $\mathrm{x}$ & & & & $\mathrm{x}$ & $\mathrm{x}$ & & $\mathrm{x}$ \\
\hline cf. Pinnularia ignobilis & & & $\mathrm{x}$ & & & & & & & \\
\hline Pinnularia microstauron & & $\mathrm{x}$ & $\mathrm{x}$ & $\mathrm{x}$ & & & & & $\mathrm{x}$ & \\
\hline Pinnularia microstauron var. ambigua & & & & $\mathrm{x}$ & & & & & & \\
\hline Stauroneis anceps fa. gracilis & & & & $\hat{\Lambda}$ & & & & $\mathrm{x}$ & & \\
\hline cf. Tabularia tabulata & & & & $\mathrm{x}$ & & $\mathrm{x}$ & & & & \\
\hline \multicolumn{11}{|l|}{ Chlorophyta } \\
\hline Chlamydomonas aff. nivalis & & $\mathrm{x}$ & & $\mathrm{x}$ & & & & & & $\mathrm{x}$ \\
\hline Chlamydomonas subcaudata & $x$ & & & & & & & & & \\
\hline Chlamydomonas sp. 1 & $\mathrm{x}$ & & & & & $x$ & & & & \\
\hline Chlamydomonas sp. 2 & & $\mathrm{x}$ & & & & & $x$ & $x$ & & \\
\hline Chlamydomonas sp. 3 & $\mathrm{x}$ & $\mathrm{x}$ & $\mathrm{x}$ & $\mathrm{x}$ & $\mathrm{x}$ & $\mathrm{x}$ & & $\mathrm{x}$ & & \\
\hline Chlamydomonas sp. 4 & $\mathrm{x}$ & & $\mathrm{x}$ & $\mathrm{x}$ & $\mathrm{x}$ & $\mathrm{x}$ & $\mathrm{x}$ & $\mathrm{x}$ & $\mathrm{x}$ & \\
\hline Cosmarium laeve & & & & & & & $\mathrm{x}$ & & & \\
\hline Cylindrocystis brebisonii & & $\mathrm{x}$ & & $\mathrm{x}$ & $\mathrm{x}$ & $\mathrm{x}$ & & & & \\
\hline Desmotetra sp. (spore) & & & & & & $\mathrm{x}$ & & & & \\
\hline Koliella tatrae & & $\mathrm{x}$ & $\mathrm{x}$ & $\mathrm{x}$ & $\mathrm{x}$ & $\mathrm{x}$ & & & & \\
\hline Raphidonema nivale & & $\mathrm{x}$ & $\mathrm{x}$ & & $\mathrm{x}$ & & & & & \\
\hline Tetrastrum sp. & & & & & & & & $\mathrm{x}$ & & \\
\hline \multicolumn{11}{|l|}{ Cryptophyceae } \\
\hline cf. Cryptomonas sp. & & & & & & & $\mathrm{x}$ & & & \\
\hline \multicolumn{11}{|l|}{ Chrysophyceae } \\
\hline Chrysophyceae unid. 1 & & & & & & & & $\mathrm{x}$ & & \\
\hline Chrysophyceae unid. 2 & & $\mathrm{x}$ & $\mathrm{x}$ & $\mathrm{x}$ & $\mathrm{x}$ & $\mathrm{x}$ & $\mathrm{x}$ & $\mathrm{x}$ & $\mathrm{x}$ & \\
\hline Chrysophyceae unid. 3 & & $\mathrm{x}$ & $\mathrm{x}$ & $\mathrm{x}$ & $\mathrm{x}$ & $\mathrm{x}$ & & & & \\
\hline Chrysophyceae unid. 4 & & & $\mathrm{x}$ & $\mathrm{x}$ & $\mathrm{x}$ & $\mathrm{x}$ & & & & \\
\hline cf. Ochromonas sp. & & $\mathrm{x}$ & & $\mathrm{x}$ & & $\mathrm{x}$ & & & & \\
\hline Cysts of Chrysophyceae & & $\mathrm{x}$ & & & $\mathrm{x}$ & $\mathrm{x}$ & $\mathrm{x}$ & $\mathrm{x}$ & $\mathrm{x}$ & $\mathrm{x}$ \\
\hline \multicolumn{11}{|l|}{ Dictyochophyceae } \\
\hline \multirow{2}{*}{\multicolumn{11}{|c|}{ Tribophyceae }} \\
\hline & & & & & & & & & & \\
\hline Tribonema sp. & & $\mathrm{x}$ & & $\mathrm{x}$ & & & & & & \\
\hline Unidentified nanoeukaryote (3-6 $\mu \mathrm{m})$ & & & & & & & $\mathrm{x}$ & & & \\
\hline
\end{tabular}

their identification was not possible under the light microscope. Another strictly planktonic group, Volvocales (Chlorophyta), was represented by several species of the genus Chlamydomonas, but their densities were only significant in the eutrophic Pingüi Pond (between 200 and 350 ind. $\mathrm{ml}^{-1}$ ). 


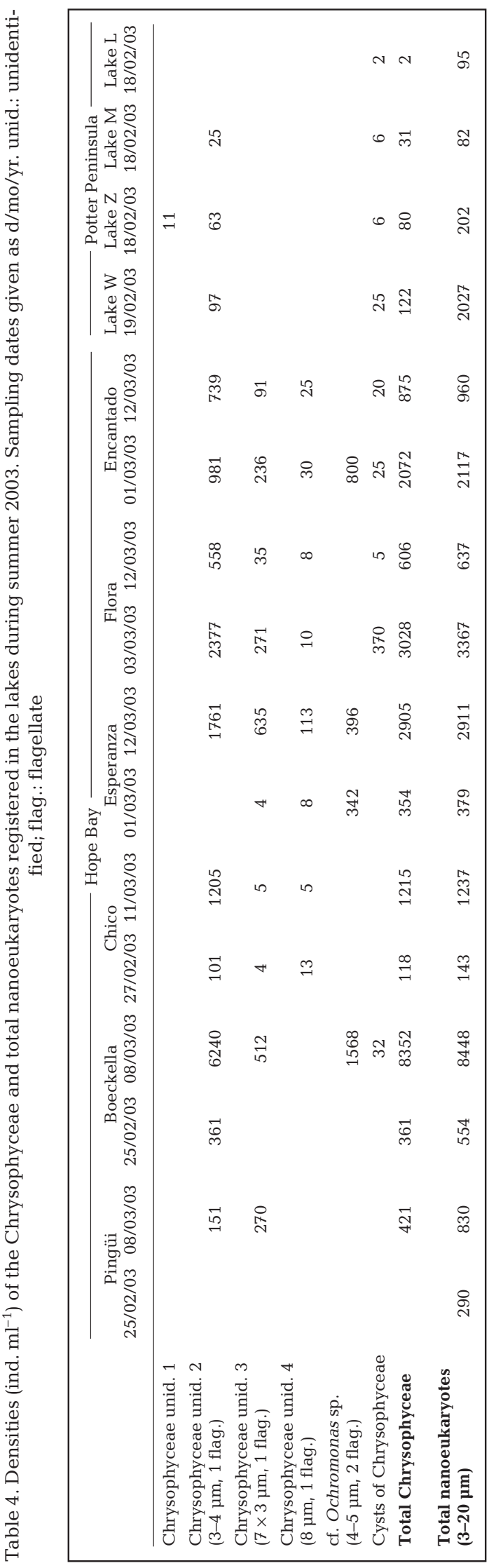

\section{DISCUSSION}

The freshwater ecosystems of Antarctica possess a very simple structure when compared with those of the Arctic and lower latitudes. Convey (2001) demonstrated that the diversity in Antarctica shows a general trend of reduction along a transect of increasing environmental extremes, from sub-Antarctic to the continental Antarctic. Even when propagules arrive, since geographical barriers would not restrict microbial eukaryotic dispersion (Finlay 2002), the potential colonisers are exposed to a second selective filter. As pointed out by Vincent (2000), the extreme environmental conditions of Antarctica (low temperature, short variations in light intensity and photoperiod and short ice-free growing season) exert a strong selection pressure on the propagules. Ellis-Evans (1996) and Laybourn-Parry et al. (2001) suggested that such extreme conditions constrain plankton diversity in Antarctic freshwater ecosystems. Our microscopic observations also support this view. Most nanoalgae found during the present survey (almost all diatoms and several green algae) correspond to tychoplanktonic species, while the number of truly nanoplanktonic taxa was fairly low, representing less than $40 \%$ of the total number of taxa found in each sample (between 3 and 8 taxa per sample).

The comparison of plankton communities using PCRbased methods presents some uncertainties due to different methodological problems (von Wintzingerode et al. 1997). Particularly for DGGE, there are clear limitations (Muyzer \& Smalla 1998, Kisand \& Wikner 2003)the low amount of sequence information (up to $500 \mathrm{bp}$ ), the low resolution in band separation between fragments with very similar sequences, and the maximum number of different DNA fragments that can be separated, which selects for the predominant members of the community-and thus rare species are unlikely to be detected. Despite these limitations, the total number of bands obtained in a DGGE analysis somehow reflects the predominant taxa in each sample (Casmayor et al. 2002). In the present study, a mean of 13 bands per sample was obtained in the DGGE. Typically, each sample was represented by a few intense bands (1 to 6 ) and several weaker bands (3 to 20). We are aware of potential PCR biases that compromise quantitative interpretation of band intensity (Schauer et al. 2003); hence, we never infer cell abundances from intensity values of the different bands. However, relative band intensity of DGGE fingerprints seems to be informative for comparative studies and can be used to follow relative changes of particular populations. In this sense, the predominance of chrysophytes among the sequenced bands, always present at a high relative intensity (on average $39 \%$ of band intensity 
considering all the samples analysed), agrees well with our microscopic observations.

Chrysophyceae often dominate Antarctic lakes, but while this algal group was mentioned in many papers, most of the references included, if any, just a few genera. In particular, Ochromonas and Chromulina were more frequently reported (Vincent 1981, Hawes 1990, Izaguirre et al. 1993, 2001, Spaulding et al. 1994, Laybourn-Parry et al. 1995, 1996, 1997, Lizotte et al. 1996, Mataloni \& Tesolín 1997, Ellis-Evans et al. 1998, Izaguirre et al. 1998, Mataloni et al. 1998, Zipan \& Deprez 2000). However, their identification, even at the generic level, was often impossible. Our past research revealed the presence of at least 6 different species of Chrysophyceae belonging to the genera Ochromonas, Chromulina and cf. Chrysidalis in the Hope Bay lakes studied, but 2 or 3 remained as unidentified taxa (Allende \& Izaguirre 2003, Izaguirre et al. 2003). In the present study, 5 different morphotypes were recognised, including 1 Ochromonas-like species, several unicellular flagellated as well as some chrysophyte cysts.

Andersen et al. (1999) performed a rigorous phylogenetic analysis of chrysophyte sequences, in which they identified 7 large clades, and concluded that flagellar number defined these clades. In our tree constructed by maximum-likelihood, using both our chrysophyte sequences and many sequences from GenBank, we recovered roughly the same clades. Band 4 appeared to be associated with clade $\mathrm{E}$ of chrysophytes (according to the reconstruction by Andersen et al. 1999), which corresponded to the order Chrysosphaerales (only 1 visible flagella). Band 4 appeared only in Lakes L and Z of Potter Peninsula; however, we were not able to identify any morphotype restricted to these 2 lakes. Only Chrysophyceae unid. 1 appeared exclusively in Lake $L$ at a very low concentration.

Sequences of Bands 5 and 6, which were highly similar $(99.1 \%)$, seemed to appear within clade C. This clade contained only biflagellate taxa, including Ochromonadales, and was weakly supported by Andersen et al.'s (1999) reconstruction. It was clear that these 2 bands were not related to any of the other clades (A, B1, B2, E and F), which seem to be welldefined groups with better bootstrap support. Our observation under the microscope revealed the presence of at least 1 naked biflagellate chrysophyte that could tentatively correspond to one or both of these bands. However, in contrast to what we would expect, this Ochromonas-like species was found in only 4 out of the 16 samples. Chrysophyceae unid. 2 and Ochromonas-like species are very similar in size and shape, their main morphologic difference being the presence of 1 or 2 flagella, respectively. Detailed observation under a light microscope at $1000 \times$ magnification allows perfect identification of the number of flagella. Nevertheless, samples in the inverted microscope are routinely counted at $400 \times$. These differences in magnification can be critical when small naked organisms of ca. 3 to $4 \mu \mathrm{m}$ are counted. Considering these limitations, some Ochromonas could have been erroneously counted as uniflagellate in the same samples, which might explain the apparent contradiction between microscopic and molecular results. We are inclined to consider that Bands 5 and 6 correspond to a biflagellate organism (Ochromonas-like species).

It is necessary to stress that Chrysophyceae unid. 2, which appeared at a high abundance in most lakes, was identified in previous studies carried out in Hope Bay as Chromulina (Allende \& Izaguirre 2003, Izaguirre et al. 2003). Even though most of the DGGE signal was recovered and prominent bands were sequenced, we did not find any band clearly belonging to the Chromulinales. Consequently, these results drive us to be more conservative in the classification of this taxa previously determined as Chromulina. Finally, Band 1 is completely different from any known Chrysophyte sequence, while Band 10 could not be clearly assigned to any clade. This latter band has a low similarity (93\%) with Cyclonexis anunularis (clade D, sensu Andersen et al. 1999).

Two sequences were identified as Chlorophyceae: Band 7 corresponded to a non-identified chlorococcalean (99.3\%), while Band 8 showed a low similarity with a cultured species of Raphidonema brevirostra (93.1\%). Even though Raphidonema is a common cryobiontic algae frequently reported for lakes from Hope Bay and other Antarctic regions (Vinocur \& Unrein 2000, Izaguirre et al. 2001, 2003), the low quality of this last sequence does not allow us to make any conjecture about this sequence. Several Chlamydomonas sp. were also observed under the microscope, although they only appeared in significant numbers in the eutrophic Pingüi Pond. Unfortunately, the 3 most intense bands of this lake could not be sequenced.

Band 9 showed the highest similarity $(99.6 \%)$ with a sequenced species, corresponding to Tabularia tabulata. The presence of this species in Esperanza Lake was confirmed by microscope observations. The occurrence of diatoms in the plankton of Antarctic lakes is occasional, since they are usually associated with benthic algal mats. Almost all diatoms found in the plankton samples had been previously recorded from the algal mats of the studied lakes (Vinocur \& Pizarro 1995, 2000).

Another interesting finding from our study was the similarity $(95.2 \%)$ of the sequence from Band 3 to Apedinella radians (Pedinellales, Dictyochophyceae). The sequence was found in 2 lakes from Potter Penin- 
sula and in the 3 connected lakes from Hope Bay. Moreover, it appeared exclusively in the oligotrophic lakes. Although Pseudopedinella, another genus of Dictyochophyceae, is commonly found in high latitude oligotrophic lakes of the northern hemisphere (Isaksson et al. 1999, Hobbie et al. 2000), this class had never been reported from Antarctic freshwater lakes. Butler et al. (2000) observed the presence of small motile species, and they suggested that they could belong to the genus Pseudopedinella, although its presence was not confirmed. In our samples, organisms resembling Pseudopedinella (with a radial symmetry, 3 to 6 chloroplasts and 5 to $8 \mu \mathrm{m}$ in diameter) were observed under light microscopy in Esperanza, Flora and Encantado Lakes. To our knowledge, this is the first record of a Dictyochophyceae in Antarctic lakes.

Band 11 exhibited the lowest similarity to cultured taxa $(90 \%)$, and a high similarity $(98.5 \%)$ with an uncultured clone with phylogenetic affinity to Cercozoa. We suspect that Band 11 could correspond to a heterotrophic nanoflagellate (HNF), but this suggestion cannot be confirmed. In general, the studies on the microbial plankton communities from Antarctic lakes report HNF as a 'black box' without any detailed taxonomic analysis (Laybourn-Parry et al. 1996, 1997, Laybourn-Parry 1997, Bell \& Laybourn-Parry 1999, Butler 1999b, Roberts et al. 2000). This is obviously a group that needs further molecular studies in these environments.

Analysing the DGGE fingerprints, it is evident that many lakes in both regions studied shared several common sequences, despite being $220 \mathrm{~km}$ apart and one of the areas being an island. In particular, 2 band positions belonging to Chrysophyceae (Bands 5 and 6) appeared in most of the samples. These 2 bands alone accounted for $23 \%$ of the total DGGE signal considering all the samples analyzed. Their high genetic similarity suggests that they probably represent 2 different species from the same genus and presumably also have morphological similarities; consequently, it is very likely that they are virtually impossibly to distinguish under the light microscope. These 2 phylogenetically related taxa appeared to be common in most of the studied environments. This fact would suggest that some nanoplanktonic species belong to taxa that are well-adapted to the Antarctic ecosystem. The similarity in microbial composition among lakes from different places of maritime Antarctica is possibly due to the local dispersal of organisms by different vectors: atmospheric circulation, ocean currents, birds, marine mammals and human influence (Vincent 2000). In contrast, local conditions could also influence the distribution of other chrysophyte species, since Bands 4 and 10 appeared exclusively in the lakes from Potter Peninsula.
Trophic status has been reported as one of the most important factors influencing plankton composition of Antarctic lakes (Hawes 1990, Izaguirre et al. 1998). DGGE band patterns and cluster analyses are consistent with these observations. Three intense unsequenced bands appeared only in the eutrophic Pingüi Pond, while one Chrysophyceae (Band 1) was found exclusively in Boeckella Lake (mesotrophic). In contrast, 4 sequences belonging to 1 Dictyochophyceae (Band 3), 2 Chrysophyceae (Bands 4 and 10) and probably 1 Cercozoa (Band 11) were restricted to the oligotrophic lakes. These results reflect the trophic preferences of some taxa.

This work constitutes the first comparison of nanoplanktonic assemblages from Antarctic lakes using DGGE fingerprinting and 18S rDNA sequencing in conjunction with microscopic analysis. Our results show that even though many nanoplanktonic organisms could be identified using morphological cell features, no morphotypes within the Chrysophyceae (the most abundant group in our lakes) could be classified with certainty within a known genus. Moreover, molecular analysis showed that many sequenced bands had a low similarity to sequenced species. Consequently, we were generally unable to assign them to the species forming the assemblages of each lake. This is because many organisms are not yet retrieved in culture or not yet characterised by its $18 \mathrm{~S}$ rDNA. In particular, despite the great number of sequences registered in GenBank, no Chrysophyceae sequences come from Antarctic lakes. In contrast, even though no 18S rDNA clone libraries are yet completed from Antarctic lakes (and very few from other freshwater systems), 5 out of the 1 sequenced positions had higher similarity with sequences retrieved from clone libraries than from cultured organisms. This highlights the importance of generating environmental sequences that could represent abundant but 'uncultivable' organisms; this was particularly evident for the 'novel alveolates' and 'novel stramenopiles' recently discovered in the sea, which are exclusively found in clone libraries (Massana et al. 2004).

It is also necessary to take into account the importance of endemism in Antarctica. Despite many cosmopolitan species being recorded in the region, there are described taxa exclusive to this continent (Andreoli et al. 1998, 1999, Komárek 1999). In particular, Komárek (1999) considered that about $60 \%$ of Cyanobacteria species in King George Island (South Shetlands, maritime Antarctica) were probably endemic. The existence of endemic species has probably been underestimated since most of the taxonomical determinations were based on literature from other latitudes. The Antarctic region is more isolated than other parts of the world, and this geographic isolation would favour evo- 
lutionary divergence from microorganisms arriving to the continent from temperate latitudes (Vincent 2000).

Our results show that some of the nanoplanktonic taxa appeared in most of the lakes while others were restricted to certain trophic or local conditions. The molecular identification, confirmed by microscopical observation, showed a dominance of chrysophytes and also revealed the presence of a Dictyochophyceae organism, a class that has never before been recorded in Antarctic lakes. Although the trophic role of nanoplankton in microbial Antarctic food webs has been well studied, the biodiversity within this group is still uncertain. In particular, the diversity and abundance of Chrysophyceae deserve further work to elucidate their taxonomic position, genetic affinities and role in Antarctic microbial food webs.

Acknowledgements. The Antarctic expedition was supported by the 'Instituto Antártico Argentino (DNA)', in the framework of a cooperative project between this institution, UBA and ICM-CSIC. This work was supported by the Spanish projects MIXANTAR (REN2002-11396-E/ANT) and MICRODIFF (DGICYT REN2001-2120/MAR), grant SB2001-0166 from the Spanish MECyD, CONICET (Argentina) and a grant of the Argentinean 'Agencia de Promociones Científicas y Tecnológica' (BID 802 OC-AR PICT/04440). We thank the members of the Argentinean Esperanza station for their logistic support, and Dr. P. Rodriguez for her assistance with the fieldwork.

\section{LITERATURE CITED}

Allende L, Izaguirre I (2003) The role of physical stability on the establishment of steady states in the phytoplankton community of two Maritime Antarctic lakes. Hydrobiologia 502:211-224

Altschul SF, Madden TL, Schäffer AA, Zhang J, Zhang Z, Miller W, Lipman DJ (1997) Gapped BLAST and PSIBLAST: a new generation of protein database search programs. Nucleic Acids Res 25:3389-3402

Andersen RA, Van de Peer Y, Potter D, Sexton JP, Kawachi M, LaJeunesse $T$ (1999) Phylogenetic analysis of the SSU rRNA from members of the Chrysophyceae. Protist 150: $71-84$

Andreoli C, Lokhorst GM, Mani AM, Scarabel L, Moro I, La Rocca N, Tognetto L (1998) Koliella antarctica sp. nov. (Klebsormidiales) a new marine green microalga from the Ross Sea). Arch Hydrobiol Suppl Algol Stud 90:1-8

Andreoli C, Moro I, La Rocca N, Rigoni F, Dalla Valle L, Bargelloni L (1999) Pseudopleurochloris antarctica gen. et sp. nov., a new coccoid xanthophycean from pack-ice of Wood Bay (Ross Sea, Antarctica): ultrastructure, pigments and 18S rRNA gene sequence. Eur J Phycol 34:149-159

Bell EM, Laybourn-Parry J (1999) The plankton community of a young eutrophic Antarctic lake. Polar Biol 22:248-258

Bell EM, Laybourn-Parry J (2003) Mixotrophy in the Antarctic phytoflagellate, Pyramimonas gelidicola (Chlorophyta: Prasinophyceae). J Phycol 39:644-649

Burch MD (1988) Annual cycle of phytoplankton in Ace Lake, an ice covered, saline meromictic lake. Hydrobiologia 165: $59-75$

Butler HG (1999a) Temporal plankton dynamics in a maritime
Antarctic lake. Arch Hydrobiol 146(3):311-339

Butler HG (1999b) Seasonal dynamics of the planktonic microbial community in a maritime Antarctic lake undergoing eutrophication. J Plankton Res 21:2393-2419

Butler HG, Edworthy MG, Ellis-Evans JC (2000) Temporal plankton dynamics in an oligotrophic maritime Antarctic lake. Freshw Biol 43:215-230

Casamayor E, Pedrós-Alió C, Muyzer G, Amann R (2002) Microheterogeneity in 16S ribosomal DNA-defined bacterial populations from a stratified planktonic environment is related to temporal changes and to ecological adaptations. Appl Environ Microbiol 68:1706-1714

Convey P (2001) Antarctic ecosystems. In: Levin SA (ed) Encyclopedia of biodiversity 1. Academic Press, San Diego, CA, p 171-184

Corte A (1962) Algas de agua dulce en lagos semicongelados de Bahía Esperanza, Península Antártica. Contrib Inst Antárct Argentino 69:1-38

DeLong EF (1992) Archaea in coastal marine environments. Proc Natl Acad Sci USA 89:5685-5689

Díez B, Pedrós-Alió C, Massana R (2001a) Study of genetic diversity of eukaryotic picoplankton in different oceanic regions by small-subunit rRNA gene cloning and sequencing. Appl Environ Microbiol 67:2932-2941

Díez B, Pedrós-Alió C, Marsh TL, Massana R (2001b) Application of denaturing gradient gel electrophoresis (DGGE) to study the diversity of marine picoeukaryotic assemblages and comparison of DGGE with other molecular techniques. Appl Environ Microbiol 67:2942-2951

Drago E, Paira A (1987) Informe de la campaña antártida de verano 1986/87. Instituto Antártico Argentino, Buenos Aires

Ellis-Evans JC (1991) Numbers and activity of bacterio- and phytoplankton in contrasting maritime Antarctic lakes. Verh Int Ver Limnol 24:1149-1154

Ellis-Evans JC (1996) Microbial diversity and function in Antartic freshwater ecosystems. Biodivers Conserv 5: 1395-1431

Ellis-Evans JC, Laybourn-Parry J, Bayliss P, Perriss SJ (1998) Physical, chemical and microbial community characteristics of the Larsemann Hills, Continental Antarctica. Arch Hydrobiol 141(2):209-230

Finlay BJ (2002) Global dispersal of free-living microbial eukaryote species. Science 296:1061-1063

Franzmann PD (1996) Examination of Antarctic prokaryotic diversity through molecular comparisons. Biodivers Conserv 5:1295-1305

Fuhrman JA, McCallum K, Davis AA (1992) Novel major archaebacterial group from marine plankton. Nature 356: 148-149

Giovannoni SJ, Britschgi TB, Moyer CL, Field KG (1990) Genetic diversity in Sargasso Sea bacterioplankton. Nature 345:60-63

Hawes I (1990) Eutrophication and vegetation development in maritime Antartic lakes. In: Kerry KR, Hempel G (eds) Antartic ecosystems. Ecological change and conservation. Springer-Verlag, Berlin, p 83-90

Hobbie JE, Bahr M, Bettez N, Rublee PA (2000) Microbial food webs in oligotrophic Arctic lakes. In: Bell CR, Brylinksy M, Johnson-Green P (eds) Microbial biosystem: new frontiers. Proceedings of the 8th International Symposium on Microbial Ecology. Atlantic Canada Society for Microbial Ecology, Halifax, p 293-298

Isaksson A, Bergström AK, Blomqvist $\mathrm{P}$, Jansson $\mathrm{M}$ (1999) Bacterial grazing by phagotrophic phytoplagellates in a deep humic lake in northern Sweden. J Plankton Res 21: $247-268$ 
Izaguirre I, Mataloni G, Vinocur A, Tell G (1993) Temporal and spatial variations of phytoplankton from Boeckella Lake (Hope Bay, Antartic Peninsula). Antarct Sci 5:137-141

Izaguirre I, Vinocur A, Mataloni G, Pose M (1998) Comparison of phytoplankton communities in relation to trophic status in lakes from Hope Bay (Antarctic Peninsula). Hydrobiología 369/370:73-87

Izaguirre I, Mataloni G, Allende L, Vinocur A (2001) Summer fluctuations of microbial planktonic communities in a eutrophic lake-Cierva Point, Antarctica. J Plankton Res 23:1095-1109

Izaguirre I, Allende L, Marinone MC (2003) Comparative study of the planktonic communities of three lakes of contrasting trophic status at Hope Bay (Antarctic Peninsula). J Plankton Res 25:1079-1097

Kisand V, Wikner J (2003) Limited resolution of 16S rDNA DGGE caused by melting properties and closely related DNA sequences. J Microbiol Methods 54:183-191

Komárek J (1999) Diversity of cyanoprokaryotes (cyanobacteria) of King George Island, maritime Antarctica-a survey. Arch Hydrobiol Suppl Algol Stud 94:181-193

Laybourn-Parry J (1997) The microbial loop in Antarctic lakes. In: Lyons C, Howard-Williams C, Hawes I (eds) Ecosystems processes in Antarctic ice-free landscapes. Balkema, Rotterdam, p 231-239

Laybourn-Parry J, Bayliss P, Ellis-Evans JC (1995) The dynamics of heterotrophic nanoflagellates and bacterioplankton in a large ultra-oligotrophic Antarctic lake. J Plankton Res 17:1835-1850

Laybourn-Parry J, Ellis-Evans JC, Butler H (1996) Microbial dynamics during summer ice-loss phase in maritime antarctic lakes. J Plankton Res 18:495-511

Laybourn-Parry J, James MR, McKnigh DM, Priscu J, Spaulding SA, Shiel R (1997) The microbial plankton of Lake Fryxell, southern Victoria Land, Antarctica, during the summers of 1992 and 1994. Polar Biol 17:62-68

Laybourn-Parry J, Roberts EC, Bell EM (2000) Mixotrophy as a survival strategy among planktonic protozoa in Antarctic lakes. In: Davison W, Howard-Williams C, Broady P (eds) Antarctic ecosystems: model for a wider ecological understanding. The Caxton Press, Christchurch, p 33-40

Laybourn-Parry J, Hofer JS, Sommaruga R (2001) Viruses in the plankton of freshwater and saline Antarctic lakes. Freshw Biol 46:1279-1287

Lindström ES (2000) Bacterioplankton community composition in five lakes differing in trophic status and humic content. Microb Ecol 40:104-113

Lindström ES (2001) Investigating influential factors on bacterioplankton community composition - results from a field study of five mesotrophic lakes. Microb Ecol 42:598-605

Lindström ES, Leskinen E (2002) Do neighbouring lakes share common taxa of bacterioplankton? Comparison of $16 \mathrm{~S}$ rDNA fingerprints and sequences from three geographic regions. Microb Ecol 44:1-9

Lizotte MP, Sharp TR, Priscu JC (1996) Phytoplankton dynamics in the stratified water column of Lake Bonney, Antarctica. I. Biomass and productivity during the winter-spring transition. Polar Biol 16:155-162

López-García P, Rodríguez-Valera F, Pedrós-Alió C, Moreira D (2001) Unexpected diversity of small eukaryotes in deep-sea Antarctic plankton. Nature 409:603-607

Maidak BL, Cole JR, Lilburn TG, Parker CT Jr and 6 others (2001) The RDP-II (Ribosomal Database Project). Nucleic Acids Res 29:173-174

Marker AFH, Nush A, Rai H, Reimann B (1980) The measurement of photosynthetic pigments in freshwater and standardization of methods: conclusions and recommen- dations. Arch Hydrobiol Beih Ergeb Limnol 14:91-106

Marshall W, Laybourn-Parry J (2002) The balance between photosynthesis and grazing in Antarctic mixotrophic cryptophytes during summer. Freshw Biol 47:2060-2070

Massana R, Guillou L, Díez B, Pedros-Alió C (2002) Unveiling the organisms behind novel eukaryotic ribosomal DNA sequences from the ocean. Appl Environ Microbiol 68: $4554-4558$

Massana R, Balagué V, Guillou L, Díez B, Pedros-Alió C (2004) Picoeukaryotic diversity in an oligotrophic coastal site studied by molecular and culturing approaches. FEMS Microbiol Ecol 50:231-243

Mataloni G, Tesolín G (1997) A preliminary survey of cryobiontic algal communities from Cierva Point (Antarctic Peninsula). Antarct Sci 9(3):250-258

Mataloni G, Tesolín G, Tell G (1998) Characterization of a small eutrophic Antarctic Lake on the basis of algal assemblages and water chemistry. Polar Biol 19:107-114

Mataloni G, Tesolín G, Sacullo F, Tell G (2000) Factors regulating summer phytoplankton in a highly eutrophic Antarctic lake. Hydrobiologia 432:65-72

McKnight DM, Howes BL, Taylor CD, Goehringer DD (2000) Phytoplankton dynamics in a stably stratified Antarctic lake during winter darkness. J Phycol 36:852-861

Moon-van der Staay SY, De Wachter R, Vaulot D (2001) Oceanic 18S rDNA sequences from picoplankton reveal unsuspected eukaryotic diversity. Nature 409:607-610

Muyzer G, Smalla K (1998) Application of denaturing gel gradient (DGGE) and temperature denaturing gel gradient electrophoresis (TGGE) in microbial ecology. Antonie Leeuwenhoek 73:127-141

Muyzer G, Brinkhoff T, Nübel U, Santegoeds C, Schäfer H, Wawer C (1997) Denaturing gradient gel electrophoresis (DGGE) in microbial ecology. In: Akkermans ADL, van Elsas JD, de Bruijn FJ (eds) Molecular microbial ecology manual. Kluwer Academic, Dordrecht, p 1-27

Nusch EA (1980) Comparison of different methods for chlorophyll and phaeopigment determination. Arch Hydrobiol Beih Ergeb Limnol 14:14-36

Pearce DA (2000) A rapid, sensitive method for monitoring bacterioplankton community dynamics, applied to Antarctic freshwater lakes. Polar Biol 23:352-356

Pearce DA (2003) Bacterioplankton community structure in a maritime Antarctic oligotrophic lake during a period of holomixis, as determined by denaturing gradient gel electrophoresis (DGGE) and fluorescence in situ hybridization (FISH). Microb Ecol 46:92-105

Pearce DA, Butler HB (2002) Short term stability of the microbial community structure in a maritime Antarctic lake. Polar Biol 25:479-487

Pearce DA, van der Gast CJ, Lawley B, Ellis-Evans JC (2003) Bacterioplankton community diversity in a maritime Antarctic lake, determined by culture-dependent and cultureindependent techniques. FEMS Microbiol Ecol 45:59-70

Priddle J, Hawes I, Ellis-Evans JC, Smith TC (1986) Antartic aquatic ecosystems as habitats for phytoplankton. Biol Rev 61:199-238

Roberts E, Laybourn-Parry J, McKnight D, Novarinos G (2000) Stratification dynamics of microbial loop communities. Freshw Biol 44:649-661

Schauer M, Massana R, Pedrós-Alió C (2000) Spatial differences in bacterioplankton composition along the Catalan coast (NW Mediterranean) assessed by molecular fingerprinting. FEMS Microbiol Ecol 33:51-59

Schauer M, Balagué V, Pedrós-Alió C, Massana R (2003) Seasonal canges in the taxonomic composition of bacterioplankton in a coastal oligotrophic system. Aquat Microb 
Ecol 32:1163-174

Spaulding SA, McKnight DM, Smith RL, Dufford R (1994) Phytoplankton population dynamics in perennially icecovered Lake Fryxell, Antarctica. J Plankton Res 16(5): $527-541$

Thompson JD, Higgins DG, Gibson TJ (1994) CLUSTAL W: improving the sensitivity of progressive multiple sequence alignment through sequence weighting, positions-specific gap penalties and weight matrix choice. Nucleic Acids Res 22:4673-4680

Torsvik V, Daae FL, Sandaa RA, Øvreas L (1998) Novel techniques for analysing microbial diversity in natural and perturbed environments. J Biotechnol 64:53-62

Tranvik LJ, Hansson LA (1997) Predator regulation of aquatic microbial abundance in simple food webs of sub-Antarctic lakes. Oikos 79:347-356

Utermöhl H (1958) Zur Vervollkommnung der quantitativen Phytoplankton-methodik. Mitt Int Ver Theor Angew Limnol 9:1-38

van Hannen EJ, van Agterveld MP, Gons HJ, Laanbroek HJ (1998) Revealing genetic diversity of eukaryotic microorganisms in aquatic environments by denaturing gradient gel electrophoresis. J Phycol 34:206-213

van Hannen EJ, Zwart G, van Agterveld MP, Gons HJ, Ebert J, Laanbroek HJ (1999) Changes in bacterial and eukaryotic community structure after mass lysis of filamentous cyanobacteria associated with viruses. Appl Environ Microbiol 65:795-801

Editorial responsibility: David Caron,

Los Angeles, California, USA
Venrick EL (1978) How many cells to count? In: von Sournia A (ed) Phytoplankton manual. UNESCO, Paris, p 167-180

Vincent WF (1981) Production strategies in Antarctic inland waters: phytoplankton eco-physiology in a permanently ice-covered lake. Ecology 62(5):1215-1224

Vincent WF (2000) Evolutionary origins of Antarctic microbiota: invasion, selection and endemism. Antarct Sci 12: 374-385

Vincent WF, Bowman J, Powell L, McMeekin T (2000) Phylogenetic diversity of picocyanobacteria in Artic and Antarctic ecosystems. Proc 8th Int Symp Microb Ecol 8:317-322

Vinocur A, Pizarro H (1995) Periphyton flora of some lotic and lentic environments of Hope Bay (Antarctic Peninsula). Polar Biol 15:401-414

Vinocur A, Pizarro H (2000) Microbial mats of twenty-six lakes fom Potter Peninsula, King George Island, Antarctica. Hydrobiologia 437:171-185

Vinocur A, Unrein F (2000) Typology of lentic water bodies at Potter Peninsula (King George Island, Antarctica) based on physical-chemical characteristics and phytoplankton communities. Polar Biol 23:858-870

von Wintzingerode F, Goebel UB, Stackebrandt E (1997) Determination of microbial diversity in environmental samples: pitfalls of PCR-based rRNA analysis. FEMS Microbiol Rev 21:213-229

Zipan W, Deprez PP (2000) Study on ecological structures of coastal lakes in Antarctic continent. Chinese J Polar Sci 11(2):147-160

Submitted: July 8, 2004; Accepted: June 9, 2005

Proofs received from author(s): September 27, 2005 